\title{
For a Theory that is Both Critical and Mathematical: Handelman, Matthew, The Mathematical Imagination: On the Origins and Promise of Critical Theory ${ }^{1}$
}

\author{
Jessie Joshua Z. Lino \\ Esmeralda A. Manlulu
}

\section{Prologue: Critical or Mathematical?}

\begin{abstract}
gustin Martin G. Rodriguez's constant use of the term tradition in referring to critical theory as a research interest of our living Filipino 1 scholars, implying the Frankfurt School becoming somewhat equivalent to a mainstream philosophy in the Philippines, is an inevitable truth which must not be ignored. ${ }^{2}$ Indeed, from the post-1980s second wave
\end{abstract}

\footnotetext{
${ }^{1}$ New York: Fordham University Press, 2019, 256 pp.

${ }^{2}$ See Agustin Martin G. Rodriguez, "Problematizing Critical Theory: Arriving at a More Critical Theory," in Kritike, 12 (April 2019). In the Philippines, specifically in the academe, critical theory is both a growing tradition and an influence in the methods and directions of doing philosophical activities, aimed towards a critique of Philippine cultural, economic literary, and social realities. While ideology-critique has sweepingly been considered a standard method, one cannot deny that the majority of contributions and research by our Filipino practitioners of critical theory are directed at generating truths and explications on unmasking the ideological frames and material conditions that determine the workings of a social phenomenon (and social reality in general). Influenced by their own reading of (if not their upbringings from) the Frankfurt School tradition, the likes of Filipino scholars Paolo Bolaños, Ranilo Hermida, Jeffry Ocay, Renante Pilapil, and Agustin Martin Rodriguez brought into the Filipino philosophical fora the reading of contributions from the first three generations of the Institut für Sozialforschung. Eventually, some Filipino scholars ventured out from the limitations and shortcomings of the German tradition of the Frankfurt School towards the other traditions of critical theory such as American, French, and Italian. And aside from Filipino practitioners of philosophy, we may also consider some of the works of literary figures such as Edith Tiempo, Edel Garcellano and Caroline Hau, the works of historians Reynaldo Itelo, Filomeno Aguilar, Jr. and Vicente Rafael, the works of political economists Walden Bello and Jose Maria Sison, and the works of multidisciplinary critics such as Florentino Hornedo, E. San Juan, Jr. and Domingo Castro de Guzman as contributions to the magnitude of radical literature on Philippine critical theory that are somehow outside the strict boundaries of the academic-philosophical enterprise. See Rodriguez, "Problematizing Critical Theory," 8-9, 19-20. The inclusion of names here are based on both co-authors' selective reading of works by the aforementioned scholars. We do recognize
}

(c) 2021 Jessie Joshua Z. Lino and Esmeralda A. Manlulu https://www.kritike.org/journal/issue 29/lino\&manlulu december2021.pdf

ISSN 1908-7330

(c) BY-NC-ND 
of Filipino practitioners of philosophy up to the present, we may find staggering in height the literature produced by a number of local scholars engaging with three generations of contributions from the Institut für Sozialforschung in commentaries, critical expositions, and practical appropriations to Philippine culture, politics, and society. Admittingly, we cannot help but be thankful to Andrew Feenberg's The Philosophy of Praxis, ${ }^{3}$ Martin Jay's The Dialectical Imagination and Splinters In Your Eyes, ${ }^{4}$ and Stuart Jeffries' Grand Hotel Abyss ${ }^{5}$ for providing us new definitive histories of the Institut, as we trace from the Frankfurt School's legacy the intellectual development of the concepts and insights we make use of in our researches. A significant emerging interest we have particularly learned from them (which is perhaps stigmatized in our current research culture in the continental tradition of philosophy) is the critique and resistance against the quantification of thought and language. It simultaneously complements the humanities' and philosophy's articulated disdain to the current crisis of attempts at the mathematicization of their respective fields that heavily affects their integrity as disciplines. Edmund Husserl traces the roots of this crisis in the works of Galileo, whose idea was that the limitations of the uses of geometric and astronomic calculations could actually be used extensively towards the "mathematization of nature," where nature becomes "a mathematical manifold." 6 Centuries later, this eventually evolved into quantified data-becoming the object of criticism we find in Jerry Z. Muller's The Tyranny of Metrics, which explores and criticizes the sober reality of measurement and the obsession with metrics-based effectivity manifested within the institutions. ${ }^{7}$ But not so long ago, this same crisis was encountered by the Frankfurt School as supposedly the consequence of further progressing from the Marcusean one-dimensional rationality to the threedimensional utopia we now refer to as the digital technological age. Nonetheless, philosophy and the humanities, more so with critical theory, must persist with this impending predicament of a $21^{\text {st }}$ century state of things.

that our list is, in fact, incomplete. However, it is safe to claim that many works on critical theory by Filipino practitioners of philosophy (academic and beyond) are explicitly unenthusiastic, if not dismissive, of the methods and approaches of the mathematical disciplines and of quantified data as sources for truth-determination.

3 Andrew Feenberg, The Philosophy of Praxis: Marx, Lukács and The Frankfurt School (London: Verso, 2014).

${ }^{4}$ Martin Jay, The Dialectical Imagination: A History of the Frankfurt School and Institute of Social Research, 1923-1950 (Berkeley, California: University of California Press, 1996); and Martin Jay, Splinters in Your Eyes: Frankfurt School Provocations (London: Verso, 2020).

${ }^{5}$ Stuart Jeffries, Grand Hotel Abyss: The Lives of the Frankfurt School (London: Verso, 2017).

${ }^{6}$ Edmund Husserl, Crisis of the European Sciences and Transcendental Phenomenology: An Introduction to Phenomenological Philosophy, trans. by David Carr (Evanston: Northwestern University Press 1970), 23. Italics in original. Cf. Handelman, Mathematical Imagination, 5.

7 Jerry Z. Muller, The Tyranny of Metrics (New Jersey: Princeton University Press, 2018).

(c) 2021 Jessie Joshua Z. Lino and Esmeralda A. Manlulu https://www.kritike.org/journal/issue 29/lino\&manlulu december2021.pdf

ISSN 1908-7330 


\section{FOR A THEORY}

Amidst this crisis, we may find it curious to pose the question: Is critical theory (of the Frankfurt School tradition) mutually exclusive with mathematics? One may find it easy to merely cite Max Horkheimer and Theodor W. Adorno's disputes with Rudolf Carnap and the Vienna Circle's logical positivists, or just their dismissive attitude to calculative reason as a new form of barbarism inherited from Enlightenment rationality, in order to answer the aforementioned question. However, an entirely innovative archeology of the Frankfurt School traces its origins to a forgotten path beyond the visions of Felix Weil and Carl Grünberg, which paved the various ways for the first generation to establish the normative claims for a critique of modernity's shortcomings and of traditional theory. Matthew Handelman's The Mathematical Imagination retraces critical theory's foundations from the mathematical writings of three German-Jewish thinkers from the Weimar Republic, who were intellectual forerunners of the Institut and also Horkheimer, Adorno, and Walter Benjamin's friends: Gerhard (later Gershom) Scholem (1897-1982), Franz Rosenzweig (1886-1929), and Siegfried Kracauer (1889-1966). The book explores the underdeveloped possibilities that mathematics held for aesthetics and cultural analysis, tracing this underappreciated lineage of the early critical theorists to retrieve and realize the Enlightenment period's neglected promises of emancipation, inclusion, and universal cultural flourishing. Unlike previous intellectual narratives which explicitly claim critical theory's origins from Hegelianism, dialectical and historical materialisms, psychoanalysis, and postEnlightenment thought, Handelman's work aims to recover the lost intellectual heritage of critical theory from the "critically productive vision of mathematics in the works of Scholem, Rosenzweig, and Kracauer." 8 Such vision is conceived "[by] locating in mathematics a style of reasoning that deals productively with that which cannot be fully represented by language, history, and capital." Handelman introduces this vision as negative mathematics, by which Scholem, Rosenzweig, and Kracauer illuminates a path forward for critical theory in the digitalization of the humanities. ${ }^{9}$

Negative mathematics, with reference to the word negative, offers a complement to the type of generative negativity which Adorno locates from the Hegelian dialectic to formulate the concept of immanent critique, ${ }^{10}$ which is also similar to the analysis made by Slavoj Žižek as a dialectical moment of distortion being constitutive of a notion. Handelman, for his part, conceives this generative negativity in terms of mathematical approaches and operations to a variety of negative predicaments: absence, erasure, lack, privation, divisions, contradictions, etc. A specific example which is

${ }^{8}$ Handelman, Mathematical Imagination, 9. Modifications ours.

${ }^{9}$ Ibid., 10.

${ }^{10}$ Ibid.

(C) 2021 Jessie Joshua Z. Lino and Esmeralda A. Manlulu https://www.kritike.org/journal/issue 29/lino\&manlulu december2021.pdf ISSN 1908-7330

(c) $)$ BY-NC-ND 
rigorously analyzed and repetitively mentioned in the book is the incapability of human understanding to capture in language the very concept of the infinite; whereas in mathematics, one use of its symbol is to demarcate the domain and range of a function: $(-\infty, \infty)$. And not to mention, just the abstract modality being the nature of the mathematical objects themselves, in contrast to the real modality of actual objects, is but a general indication of how mathematics characterizes negativity in its own approach. It is this mathematical approach to negativity that which became the point of departure for Scholem, Rosenzweig, and Kracauer to establish a critical theory of history, society, culture, and art.

\section{Articulated Disdain against Mathematics}

It is worthwhile to mention that the mathematical contributions of Scholem, Rosenzweig, and Kracauer to the Frankfurt School tradition have been overshadowed by critical theory's (if not continental philosophy's) articulated disdain against mathematics. In fact, the major contributions of members of the Institut are indicative of this movement from the mathematical approaches to social sciences towards an analysis of society which they deem to be more critical and reflexive. ${ }^{11}$ To name a significantly few of them which are not explicitly mentioned in Handelman's work: Horkheimer's early essay "Traditional and Critical Theory" (1937) and his Eclipse of Reason (1947) examine the dangers of the subject's calculative reason that rendered transformation of the domination of nature into domination in society; Adorno's Against Epistemology: A Metacritique (Zur Metakritik der Erkenntnistheorie, 1970) targets on the implications of Husserl's procedure in the Logical Investigations and the objectivity discovered from a logicalmathematical perspective; Benjamin's collection of "Aphorisms," in Early Writings: 1910-1917, wherein he states that "[theory] cannot refer to reality but belongs together with language. Implicit here is an objection against

${ }^{11}$ Meanwhile, we recognize that some works of members of the Institut did not entirely abandon the mathematical enterprise-an important topic that was not addressed by Handelman in The Mathematical Imagination. On the contrary, the following works touch on the necessary (yet limited) function of calculation, demography, empirical data and quantitative approaches in each of their elaboration for a critical analysis of culture, economy and society in general: Henry Grossman's The Accumulation and Breakdown of the Capitalist System: Being Also a Theory of Crises [Das Akkumulations - Zusammenbruchsgesetz des kapitalistischen Systems (Zugleich eine Krisentheorie), 1929], Friedrich Pollock's Automation: A Study of its Economic and Social Consequences (1957), Claus Offe's essay "Inequality and the Labour Market" ("Institut für Arbeitsmarkt und Berufsforschung," 2010), and the voluminous work The Authoritarian Personality (1950), co-written by Adorno, Else Frenkel-Brunswik, Daniel J. Levinson, and R. Nevitt Sanford.

(c) 2021 Jessie Joshua Z. Lino and Esmeralda A. Manlulu https://www.kritike.org/journal/issue 29/lino\&manlulu december2021.pdf

ISSN 1908-7330 


\section{FOR A THEORY}

mathematics;"12 and Herbert Marcuse's Negations (1968), where he mentions that "mathematization is carried to the point of the calculus with the real negation of life itself ...."13 Overall, the disdain to the mathematical approaches, including the more rigid and abstract sciences, is also reflected in works that possess a more moderate tone when engaging in the issues on the effects of industrialization and technology in modern society. To name a few of them: Franz Leopold Neuman's The Democratic and the Authoritarian State (1957) examines the nature of valuations as calculations in capitalist society; Erich Fromm's "Man in Capitalistic Society" in The Sane Society (1955) examines the dangers of rigid abstractions and inevitable quantifications in the affairs of human beings within capitalist market economy; Marcuse's essays "From Ontology to Technology" (1960) and "The Problem of Social Change in the Technological Society" (1962), the latter mentioning that within the framework of mathematics, "science undertook the progressive formalization of nature, embarked on it as on an enterprise of knowledge: purely cognitive, endless domination;" 14 and Benjamin's The Work of Art in the Age of Mechanical Reproduction (Das Kunstwerk im Zeitalter seiner technischen Reproduzierbarkeit, 1935), where he examines the devaluation and depthlessness of art and aura through abstractions and quantifications in modern capitalist society.

Horkheimer nominates positivism as a "philosophical technocracy," being the culmination of a perspective that embraces the dominance of obscure objectivity of calculations, formalizations, and quantifications at the cost of negating real experiences..$^{15}$ Through the guiding spirit of Horkheimer, members of the Institut under his directorship readily engaged in disputes with members of the Vienna Circle, reinforcing their differences in doing philosophy. ${ }^{16}$ Furthermore, their disputes also contributed in stigmatizing

12 Walter Benjamin, “Aphorisms," in Early Writing: 1910-1917 (Cambridge, Massachusetts: The Belknap Press of Harvard University Press, 2011), 271. Modifications ours.

${ }^{13}$ Herbert Marcuse, Negations, trans. by Jeremy J. Shapiro (London: MayFly Books, 2009), 158.

${ }^{14}$ To supplicate the complete quotation in order to clarify Marcuse's claim: "the theoretical approach to reality in terms of mathematics becomes the authentic and effective scientific approach only if and when reality is no longer experienced (or rather: is no longer imposed upon experience) as cosmos, i.e., as a natural hierarchy of functions, time and place, values and ends. And this change in the experience of reality occurs in the practical approach to reality imposed by the organization of industrial society. Within this framework, science undertook the progressive formalization of nature, embarked on it as on an enterprise of knowledge: purely cognitive, endless domination." Herbert Marcuse, "The Problem of Social Change in the Technological Society," in the Collected Papers of Herbert Marcuse, Volume Two: Towards a Critical Theory of Society, ed. Douglas Kellner (London: Routledge, 2001), 44.

${ }^{15}$ Max Horkheimer, Eclipse of Reason (New York: Continuum Publishing Company, Inc., 2004), 41, 50 .

${ }^{16}$ Here, it is worth mentioning the following works of Frankfurt School's disputes against the method of logical positivism instigated in by the members of the Vienna Circle: Horkheimer's

(c) 2021 Jessie Joshua Z. Lino and Esmeralda A. Manlulu https://www.kritike.org/journal/issue 29/lino\&manlulu december2021.pdf ISSN 1908-7330

(cc) BY-NC-ND 
critical theory's veering away from mathematics. As Handelman (in Chapter One) traces from the Dialectic of Enlightenment (Dialektik der Aufklärung, 1944), Horkheimer and Adorno argues that mathematics offered not only tools that expands the horizon of understanding and knowledge in their simplified units and theorems. Mathematics, for both of them, also became the apparatus with which reason could formulate, calculate, estimate, and thus dominate and eliminate the natural world, including all that exists in it. ${ }^{17}$ Horkheimer and Adorno instigated this dismissive direction of critical theory from mathematics, shifting the thought of the theoreticians of culture and art away from the methodologies of the mathematical disciplines. Moreover, as expression of the manifest barbarism and heartlessness of modernity, mathematics was incapable of emancipation and relapses into restriction, coercion, and subjugation, as Horkheimer and Adorno claim:

By sacrificing thought, which in its reified form as mathematics, machinery, organization, avenges itself on a humanity forgetful of it, enlightenment forfeited its own realization. By subjecting everything particular to its discipline, it left the uncomprehended whole free to rebound as mastery over things against the life and consciousness of human beings. But a true praxis capable of overturning the status quo depends on theory's refusal to yield to the oblivion in which society allows thought to ossify. ${ }^{18}$

It was this simplistic and strange equation of mathematics with instrumental reason that crystalized the conviction of the practitioners of philosophy between the disjunctives: either critical theory or mathematicswhere the former exposes and resists societal mechanisms of control, domination, and oppression, the latter pertains to the reproduction of the social order by the repetition and mimicking of formula, operation, and symbols, which seemed indifferent to humanity in general. ${ }^{19}$ Horkheimer and Adorno have also shown how mathematics is in tension with language in

essay "The Latest Attack on Metaphysics" (1937), Adorno's essays "Sociology and Empirical Research" ("Soziologie und empirische Forschung," 1957) and "On the Logic of the Social Sciences" ("Zur Logik der Sozialwissenschaften," 1962), and Jürgen Habermas' essay "The Analytical Theory of Science and Dialectics" ("Analytische Wissenschaftstheorie und Dialektik," 1963).

${ }^{17}$ Handelman, Mathematical Imagination, 39. Cf. Ibid., 7.

${ }^{18}$ Max Horkheimer and Theodore W. Adorno, Dialectic of Enlightenment: Philosophical Fragments, trans. by Edmund Jephcott, ed. by Gunzelin Schmid Noerr (Stanford, California: Stanford University Press, 2002), 33. Cf. Handelman, Mathematical Imagination, 7.

${ }^{19}$ Handelman, Mathematical Imagination, 8.

(c) 2021 Jessie Joshua Z. Lino and Esmeralda A. Manlulu https://www.kritike.org/journal/issue 29/lino\&manlulu december2021.pdf

ISSN 1908-7330 


\section{FOR A THEORY}

terms of representation, as numbers tend to reductively simplify our thoughts, while words function as medium for expressing the raw but meaningful experiences we have. These claims were confirmed with the Vienna Circle's mathematical engagements in philosophy, being symptomatic of political quietism (during Nazi Germany) and being subject to abandon meaning as they tend to reduce thought into something else, i.e., signs, exponents, etc. With the initiatives made in the Dialectic of Enlightenment, critical theory has remained forgetful of the emancipatory potentials mathematics has contributed to the history of the Frankfurt School. And this disdain towards mathematics has pervaded in the attitude of most theorists and critics from the humanities and the social sciences even in today's digital age of quantification and information and communication technology.

\section{Negative Mathematicians: Scholem, Rosenzweig, Kracauer}

Handelman's The Mathematical Imagination promises the otherwise: that negative mathematics offers a synthesis of mathematics and critical theory, allowing us to confront one of the fundamental problems of our digital modernity: "the critique of and intervention in a digital world through critical analysis that succumbs neither to the naiveté of scientific progressivism nor the rejection of critique." 20 In the contemporary crisis of the disciplines belonging to the humanities, it is only fitting to anticipate for the advancements made by mathematics and digital technologies, in the hopes of modernizing humanistic inquiries and simultaneously addressing issues of its contemporaneity. Negative mathematics definitively functions as an intellectual ethos, which is arguably comparable to what both Raymond Geuss and Paolo A. Bolaños conceptually refer to as an ethics of thinking. It is critical in the sense that it seeks to address the immanent contradictions of reason (Vernunft) which are manifest in language, religion, society, and mass culture. ${ }^{21}$ Contrary to the rejectionist attitude to mathematics by most practitioners of critical theory, Handelman presents to us (with an overview in the "Introduction") how mathematics contributed to the foundations for a critique of the crises of modernity which is almost similar with the works of the Institut's first generation. Scholem, Rosenzweig, and Kracauer's contributions to aesthetics, epistemology, and cultural critique borrow ideas from mathematical logic, infinitesimal calculus, and projective geometry "to theorize art and culture in ways that strive to reveal and, potentially, counter

${ }^{20}$ Ibid., 11, 33-35.

${ }^{21}$ See Raymond Geuss, Outside Ethics (Princeton and Oxford: Princeton University Press, 2006), 76-77; and Paolo Bolaños, "Philosophy from the Standpoint of Damaged Life: Adorno on the Ethical Character of Thinking," Budhi, 16 (2012).

(c) 2021 Jessie Joshua Z. Lino and Esmeralda A. Manlulu https://www.kritike.org/journal/issue 29/lino\&manlulu december2021.pdf ISSN 1908-7330

(c) $\mathrm{BY}-\mathrm{NC}-\mathrm{ND}$ 
the contradictions of modern society," 22 addressing sociopolitical crises without having to resort to the positivistic science's gobbledygook for objectivity and adherence to a kind of rationality that eliminates the human condition. The politics of silence and domination entailed in logical positivism's mathematics were for Scholem, Rosenzweig, and Kracauer the sources of productive negativity specified in looking at how mathematics develops concepts and symbols which human cognition and language cannot properly grasp, represent, or merely capture in words. Adding Handelman's constant reference to the three being Jewish thinkers during the magnificent rise and fall of the Weimar Republic provides the context as to how their mathematical writings contributed to evaluating their own experiences of marginalization, exile, and social exclusion. In each of their unique ways, Handelman skillfully traces the mathematical leitmotif of generative negativity in the historical prelude to the establishment of the Institut.

Scholem's writings such as the Major Trends in Jewish Mysticism (1941) constitute negative mathematics by drawing its generative element from language's limitations in representing contents of the non-mathematical objects. Handelman reminds us (in Chapter Two) of the Leibnizian vision of mathematics being a universal language; though arbitrary in meaning, mathematical symbols may be utilized at the level of universality. In mathematical logic, the use of an abstract symbol (e.g., a variable) does not mean the total absence of objects, but rather the inexpressible representation of further complex equations. Thus, one can never exhaust the concept of the infinite through language's finite medium of terms and words. Moreover, given the arbitrariness of meaning, it implies the impossibility of the existing words that we have in order to possess exact meaning in the field of mathematics. However, it is precisely this privative structure of knowing that signifies language's totalizing characteristic of potentially reducing the meaning of the objects it represents. Scholem examines the poetics of lament, showing how in Kabbalist culture, the language of lamentation and silence express the inexpressible and from within lies the dilemma of saying the ineffable between revelation and concealment. ${ }^{23}$ Aberrant movements of the unspoken language insinuate this language of silence that is communicable without the use of semantics, phonetics, or other means of nominal reference. The inexpressibility in silence signify more than just the absence of a language, but most importantly it recognizes a creative potential, as Handelman describes: the "positive ability to signify that there are experiences that cannot be represented in language" - an insight one may find similar in Adorno and Benjamin's theory of language. ${ }^{24}$ Scholem

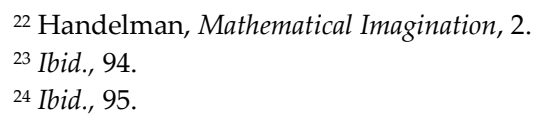

(c) 2021 Jessie Joshua Z. Lino and Esmeralda A. Manlulu https://www.kritike.org/journal/issue 29/lino\&manlulu december2021.pdf ISSN 1908-7330 


\section{FOR A THEORY}

celebrates negative mathematics' proposals for a set of technique which Handelman describes as a "negative aesthetics" - or the poetic attempts to represent silence as humanity's experience of diaspora, exile, erasure, privation, lack, and loss through the elimination of a definite representation. Negative mathematics, in Scholem, deals with linguistic problems at a moment of cultural crisis by recognizing the futility of representing them into words. The problem with trying to characterize all things through words and symbols reveals "configurations of language that captured historical and religious experiences whose extremity exceeded language limits," symbolizing the immediate inexpressibility of "privations of life in exile." 25 To use the strategy of negative mathematics in history would entail the voicing out of the silences or historical experiences of erasure, exclusion, distortion, and-in Scholem's case for the Jews-diaspora. It challenges the authority of traditional ways of looking at history, wherefore an enumeration of the silences and erasures recorded must be taken into consideration, affording a discursive space for "historical experiences and cultural practices that rationalist discourse, majority culture, and national, world-historical narratives may more readily marginalize or assimilate." 26

Meanwhile, Rosenzweig's The Star of Redemption (Der Stern der Erlösung, 1921) borrows the lessons operative of an infinitesimal calculus that circumvents the "enigma of the infinite," using its metaphorics of subjectivity, time, and motion in order to explain the truths of human action, the interconnectedness of all, and the dynamic theories of epistemology and messianism. Handelman examines (in Chapter Three) that infinitesimal calculus possesses the necessary tools to redeem the loss of subjectivity, its theoretical position, as well as the marginalized role of Judaism as bearer to truths of the messianic history of redemption. ${ }^{27}$ Rosenzweig contributes to negative mathematics a reorientation of cultural criticism where the present finite actions of individual and groups become the verifications to the messianic truths. The generative negativity of infinitesimal calculus revolves around the notion of a differential $(d x),{ }^{28}$ which for Gottfried Wilhelm Leibniz

${ }^{25} \mathrm{Ibid} ., 8$. One may also be reminded of the final proposition of Ludwig Wittgenstein's Tractatus Logico-Philosophicus, recognizing that silence meant the incapacities and limitations of articulating all objects of the world into immediate linguistic medium. Though Handelman clarifies the similarity between Wittgenstein's and Scholem's perspectives on silence as a form of incapacity and limitations of linguistic expressibility, he nevertheless mentions the theoretical rupture between them: for Scholem, silence expresses something inexpressible or least the lack of its language; whereas for Wittgenstein, silence is an expression of nothing. See Ibid., 30-31.

${ }^{26}$ Ibid., 103.

${ }^{27}$ Ibid., 106.

${ }^{28}$ Also derived in its complete original formulation as Leibniz's notation $\left(\frac{d y}{d x}\right)$, it can be observed that Handelman's preference of using the variable $d x$ is simply due to the derivative's main mathematical use - to single out the calculation of differentials, or the small changes in the

(c) 2021 Jessie Joshua Z. Lino and Esmeralda A. Manlulu https://www.kritike.org/journal/issue 29/lino\&manlulu december2021.pdf ISSN 1908-7330

(cc) BY-NC-ND 
is the infinitely small distance, and for Isaac Newton the fluxion or an infinitely small instance of motion. A differential serves as the conceptual bridge between nothingness, finitude, and infinity-generating changes of rate in motion from the sum of infinite motions to the infinitely small distances. ${ }^{29}$ In Rosenzweig's negative mathematics, the metaphor of the differential suggests the interconnectedness of all subjective actions (from origin and beyond) in relation to a multiplicity of the subject which engages as agent of the present ("the here-and-now")-in the same way that the integral, being sum of infinite numbers of quantities and widths, is referenced to a specific differential having its unique present instance. And with differentiation, it is possible to draw "lines and curves [including their trajectories] out of absences and negativity [i.e., 0 , or without quantity]." 30 The human subject, through his or her individuality, acting in the multiplicity of

variable $x$. See ibid., 107. However, with the advancing of calculus during the $18^{\text {th }}$ Century, the French mathematician Joseph Louis Lagrange (1736-1813) introduced the use of the symbol $f^{\prime}$ for the derivative of a function $f$. The new notation of the derivative in Lagrange's contribution highlights that the function $f^{\prime}$ derived from the function $f$ at a value of $x$ is $f^{\prime}(x)$. If a function $f$ is differentiable, then its derivative is $f^{\prime}$ which is called as the first derivative. Second derivative $\left(f^{\prime \prime}\right)$ exists if $f^{\prime}$ is differentiable. The same case applies with the third derivative if the second derivative is differentiable. The $n$th derivative of a function $f$, denoted as $f^{(n)}$, is the derivative of the $(n-1)$ st derivative of $f$ in which $n$ is a positive integer that is greater than one. For example, if we find all the derivatives of the function $f$ as defined by $f(x)=7 x^{2}+26 x+11$ : Using the theorems on differentiations, the first derivative is $14 x+26$, while the second derivative would be 14 . Lastly, the third derivative of the function is 0 . Though modern-day calculus still generally invoke Leibniz's notation $\left(\frac{d y}{d x}\right)$, such notation is also widely used in physics along with Lagrange's contributions: whereby $f(x)$ is generally measured in meters per second, while $d x$ in seconds; thus $f(x) d x$ is in meters, including also its integral value. See William Briggs, Lyle Cochran, Bernard Gillett, and Eric Schulz, Calculus: Early Transcendentals, 3rd ed. (New Jersey: Pearson Education, Inc.: 2019), 1-2, 875-879, 883-892.

${ }^{29}$ Handelman, The Mathematical Imagination, 107-108. Elaborating further Rosenzweig's explanations of the interconnections between nothingness, finitude and infinity using infinitesimal calculus, Handelman provides in The Mathematical Imagination two graphs derived from Eduard Riecke's Textbook for Experimental Physics (1896), presenting the methods of differentiation (Figure 3.1) and integration (Figure 3.2), depicting the slope of a graph at a given point being the slope of the tangent line to the graph on the point. With reference to Figure 3.1, the markings of points $\mathrm{P}$ and $\mathrm{P}^{\prime}$ are essential in identifying the slope of the curve at point $\mathrm{P}$. The secant line connecting $\mathrm{P}$ and $\mathrm{P}^{\prime}$ is a line through the two points on a curve. Since $\mathrm{Q}^{\prime}$ is not a point on the curve, it signifies nothingness. This point $Q^{\prime}$ plays an integral part because it serves as the identifier of the vertical change and horizontal change between points $\mathrm{P}$ and $\mathrm{P}^{\prime}$. Hence, the ratio of $\mathrm{P}^{\prime} \mathrm{Q}^{\prime}$ and $\mathrm{PQ}^{\prime}$ is the slope of the secant line which approximates the steepness of a curve. Marking of points $\mathrm{P}, \mathrm{P}^{\prime}$ and $\mathrm{Q}^{\prime}$ signifies the possibility of identifying the slope of the curve in the figure. Through differentiation, the instantaneous change of rate is (metaphorically) indicative of a finitude as specified by a point in the tangent line. Meanwhile, the points lying between $\mathrm{P}$ and $\mathrm{P}^{\prime}$ are infinite. Consequently, these infinitely many points may also render possible the creation of different secant lines (see Figure 3.2). If we identify points that are closer and closer to point $\mathrm{P}$, the secant lines will be closer and closer to the tangent line. See Handelman, Mathematical Imagination, 108.

${ }^{30}$ Handelman, Mathematical Imagination, 114. Modifications ours.

(c) 2021 Jessie Joshua Z. Lino and Esmeralda A. Manlulu https://www.kritike.org/journal/issue 29/lino\&manlulu december2021.pdf ISSN 1908-7330 


\section{FOR A THEORY}

differentials, can generate knowledge of its origin (and pre-origins, i.e., the events before lived experience) from the primordial motion that constitutes the present belongingness he or she has. It is in this sense that subjectivity renders truth to the generative workings of negativity: transition points between possessing quantity and that which possess no quantity, or what both Jews and Christians would refer to as creation from nothing. ${ }^{31}$ Knowledge of motion is only possible from us, active creators of knowledge, being the ontological reference to the sum of all motions. Does this mean we can determine the future by simply calculating the trajectory of the multiplicity of differentials? For Rosenzweig, knowledge does not signify beliefs that are proven and justified, but rather what subjects have verified through their experience, akin to Immanuel Kant's closet empiricism. ${ }^{32}$ Moreover, despite our knowledge being limited to what we have experienced, therein lies a deeper structure of temporality in motion that which confirms its direction within a continuum. For Newton, a continuum can be portrayed into a linear structure, where its continuous magnitude is not "bookended by points, but rather generated by a point as it moves continuously through space." 33 In the same way for Rosenzweig, the curve of time cannot be totalized by pointing to its origin and an undefined end, but rather it is a product of a continuous present ("the here-and-now") as it moves from beginning to end and, thus, constitute the continuum of time as a whole. This became the framework for conceptualizing the dynamic theory of epistemology and messianism. Rosenzweig wanted to show that we are able to generate knowledge about time through differentiation in two ways: "one the one hand, differentiation calculates the direction and rate of change of time at any particular time and, on the other hand, we can describe the curve of time from any particular time via its differentials." 34 As the whole determines the parts and vice versa, the continuum of all times necessitates any particular time that constitutes it, and not just the significant idealized ones (e.g., those yet to happen, the teleological yet undefined end, or the messianic promise). Mathematics, for Rosenzweig, suggests that time, as a continuum leading from the beginning of the world (i.e., creation from nothing) to the undefined end (i.e., messianic redemption), consisted not only of narratives from the past but also an infinite and expanding aggregates of moments and possibilities. The idea of the undefined yet capacious concept of continuum provides a defense for the role of Judaism in the schema towards redemption: Judaism appears before Christianity in history, confirming truths in both religions - in the same way that the "irrational"

${ }^{31}$ Ibid., 115.

32 Ibid., 124.

33 Ibid., 123. Italicization ours.

${ }^{34}$ Ibid., 124.

(c) 2021 Jessie Joshua Z. Lino and Esmeralda A. Manlulu https://www.kritike.org/journal/issue 29/lino\&manlulu december2021.pdf ISSN 1908-7330

(c) BY-NC-ND 
numbers (quantities without representation, e.g., $\pi$; as Judaism still awaits for the Messiah for expression and reference) complete the actuality of "rational" numbers (quantities represented by the ratio of integers where the denominator should not be equal to zero, e.g., 1, 2, 3, etc.; as Christianity express its faith through Jesus Christ) - both being equally necessary in the flow of the continuum of redemption, representing an infinitude of redemption through each unique subjective actions toward "an ultimate, historically unreachable goal." 35

The critical import of this version of messianism focuses not on a passive expectation of divine interventions, but, on the contrary, it is a dynamic anticipation of divine revelation in the "here-and-now," fueling a more emancipatory worldview stressed on our active engagement with the world. Handelman interprets from Rosenzweig's negative mathematics that the ideals of emancipation need not be separate from human action, as the latter's actuality reveals the fruits of revolutionary worldly engagement. For Handelman, as for Rosenzweig, the dynamic capacity of the differential to generate possibilities from negativity allows us to bring into present the truths of actual experience while "pushing its realization" from our historical experience-a lesson one may also find in the works of Ernst Bloch. Applying this in cultural studies, Rosenzweig's negative mathematics contributes for a theory of culture that takes our present active efforts to engage in the dynamics of social change, where they become proofs themselves of those unrealized possibilities. Rosenzweig's negative mathematics, Handelman contends, gave voice to the Jews regardless of their marginalized position in the history of salvation, revealing their significance in the redemption of

35 To clarify Rosenzweig's use of these mathematical concepts, it can be observed that Handelman was referring to specifically the union between sets of rational and of irrational numbers, both being the set of real numbers. Metaphorically, Handelman elaborates that both Christianity and Judaism believe in a higher being, and the way in which they accept this higher being is comparably the same as the difference of rational and irrational numbers. Let decimals be the limelight to stress out the difference between these two sets: (1) On the one hand, terminating decimals and repeating decimals are members of the set of rational numbers. We have a decimal that has a finite digit, and a decimal that is non-terminating and includes a pattern of digits (e.g., 1, 2, 3, etc.-decimals that could possibly possess patterns). These sets of rational numbers may be associated with Christianity who accepts Jesus Christ as the Messiah and the Son of God, which is metaphorically compared to a terminating decimal because its revelatory expression is definite: He is God in the flesh, who came to redeem humanity from their sins. At the same time, a non-terminating decimal that has a repeatable pattern symbolizes too that the Christian faith to Jesus Christ as the way, the truth and life, is ritually expressed in the constant religious practices for redemption and salvation; (2) And on the other hand, there exists nonterminating decimals with no repeating pattern (e.g., $\pi=3.1415926536 \ldots$ - the reference being continuous and undefined in the last instance), symbolizing the Jews' hopeful anticipation for the coming of the Messiah, whose existence is yet to provide them the full revelatory expression of Jewish faith, acting as Judaism's point of reference. See Handelman, Mathematical Imagination, 124-125, 137-138.

(c) 2021 Jessie Joshua Z. Lino and Esmeralda A. Manlulu https://www.kritike.org/journal/issue 29/lino\&manlulu december2021.pdf ISSN 1908-7330 


\section{FOR A THEORY}

mankind to which Christianity is currently the major narrative of salvation. Such messianism reveals to us the potential of our present mundane actions to illuminate, verify and behold the truths of emancipatory futures.

While Scholem constantly makes use of lessons from mathematical logic and Rosenzweig from infinitesimal calculus, Handelman sees in Kracauer's writings the possibility of bridging the void between the material dimension of experience and the logical dimension of thought via geometry as the mathematical inquiry of space. It informed negative mathematics for the conceptualization of a materialist hermeneutics of mass culture and its products, in the attempts to reconsider advancing the failed project of the Enlightenment: a reasonable and inclusive society. Geometry enables a literary approach to cultural critique which "helped confront the contradictions of modernity and, through such confrontation, potentially resolve them." ${ }^{36}$ For Kracauer, Handelman observes (in Chapter Four) that the use of geometric and architectural representation allows us to view a deeper metaphysical dimension of the materiality of our experience, causing us confront the problematics of disjunction between the forms and contents, between life and thought, in the hopes of finding an immanent sense of meaning in the apparent randomness of contemporary social life. ${ }^{37}$ The potential of geometry to render an aesthetics of theory circulates in what Kracauer calls projektionslehre, developing a materialist reading inclusive of "correspondence, projection, and examination," 38 as exemplified in his works The Detective Novel: An Interpretation (Der Detektivroman: Eine Deutung, 19221925), the essays collected in The Mass Ornament (Das Ornament der Masse, 1963), and other written pieces from the Frankfurter Zeitung. The aesthetics of theory performs its critique of reading the material products of society which are indicative of the ideological and metaphysical underpinnings and principles that govern society and culture beyond the surface, i.e., the rationality of a social order. After which, critique intervenes in the social realm by having society confront its contradictions via projecting back into the products these ideologies. In geometry, projection generates the possibility of reading these negativities, disjunctions, disconnections between the forms and matters. Moreover, projection pertains to the mathematical procedure of mapping one structure onto another, or to imagine space and figures in the faculty of intuition. ${ }^{39}$ Kracauer's well-defined example,

\footnotetext{
${ }^{36}$ Handelman, Mathematical Imagination, 8.

37 Ibid., 151.

38 Ibid., 161-163. In page 163, however, Handelman refers to the third constituent of projektionslehre not as examination, but rather "transformation."

39 Kracauer's projektionslehre, as observed by Handelman, rigidly employs not the mathematical lessons of modern-day projective geometry, but rather mainly comes from the methodical presuppositions of Euclidean plane geometry and Cartesian analytic geometry, with their use of concepts such as distances and angles. Perhaps, one may assume that Kracauer's
}

(c) 2021 Jessie Joshua Z. Lino and Esmeralda A. Manlulu https://www.kritike.org/journal/issue 29/lino\&manlulu december2021.pdf ISSN 1908-7330

(c) BY-NC-ND 
Handelman analyzes, is the idea of a detective novel being literature's "Enlightenment genre par excellence," 40 signifying the immanent unconditional triumph of rationality (i.e., the detective) over the natural world (i.e., the mystery of the crime scene).

In a supposedly well-defined society, it was thought impossible to find traces of its being unreasonable, just as capitalism works very well and systematic that it thrives despite its oppressive tendencies and amidst crises in the economy. Kracauer's negative mathematics invalidates this perspective, as it becomes possible to criticize by analyzing the rationalized creations of the social order because "their manifest rationality gave insight into the principle guiding their production." 41 Mass ornaments, by virtue of being ornaments, reveal the excess pathological rationality of mass culture, that even if they are inessential and without function, it is from this nonteleological existence that discloses the movements, patterns, and figures which are indicative of the shapes of thought in the social order. Kracauer made it possible to view geometry, a mathematical branch, not as a mechanistic tool of capitalist mass production and exploitation, but rather as method of reading projections that render legible and visible the contradictions of abstract quantities, qualities, and modalities of capitalist products-ultimately having capitalism confront its own projected contradictory rationality. ${ }^{42}$ Such rational confrontation is directed at Enlightenment's neglected promise of progress in reason and inclusion. Paying attention to those spaces marginalized by the dominant rationality, the projection entailing confrontation of our own shortcomings is similar to the mighty realism of Adorno's concept of immanent critique, in being critical too of itself. Kracauer's negative mathematics enables us to reconfigure the coordinates of the sensible world, where the materiality of our critique would bear potentials in transforming the disjunctions between experience and thought into conjunctions. Finally, Handelman claims that this geometrical cultural critique also applies to the examination, arrangement, and calculative partitioning (or worst, exclusion) of urban spaces made possible by certain

constant use of projection as a geometrical method complements with projective geometry's theoretical inquiries on how lines and shapes project into space, and also the rendering the possibility of different objects meeting in conjunction with one another at some point in infinity, where distance may become irrelevant. In the same way that Kracauer's negative mathematics generates from projective geometry's concept of infinites spaces, it become possible to view conjunctions or disjunctions between life (e.g., modernity) and thought (e.g., rationality) in the form of critique. However, Handelman carefully describes Kracauer's idea and method of projection as "is geometric projection in reverse; it reads the metaphysical shape of an object out of its corresponding, rationalized forms, flattened and contorted." Handelman, Mathematical Imagination, 162.

${ }^{40}$ Ibid., 151.

${ }^{41}$ Ibid., 165.

42 Ibid., 171.

(c) 2021 Jessie Joshua Z. Lino and Esmeralda A. Manlulu https://www.kritike.org/journal/issue 29/lino\&manlulu december2021.pdf

ISSN 1908-7330 
modern rationalities. ${ }^{43}$ In Kracauer, we may find the Cartesian natural geometry performing the political assignment of cultural critique, hoping to have a material, ideal, and corrective effect on the social orders it criticizes.

There can be no doubt that Scholem, Rosenzweig, and Kracauer's contributions for negative mathematics renders critical import to theory, portraying a lot of potentials neglected by the early critical theorists. Indeed, Handelman's work reinvigorates the avenues for critique that treats mathematics as an important cultural and aesthetic medium. ${ }^{44}$ But after a summative review of Handelman's work, The Mathematical Imagination reveals a crucial question (and a silence) which befalls into us at the end: How do these theorists of negative mathematics specifically count as significant intellectual predecessors of the Frankfurt School critical theory? Do the similarities between critical theory and negative mathematics in terms of the nature of inquiry, theoretical direction, and research variable account for Scholem, Rosenzweig, and Kracauer their proper theoretical and historical positions in the Frankfurt School tradition? Despite his constant claim that these three thinkers are friends to some of the founding members of the Institut, or the fact that their mathematical methodologies possess critical component for a theory of society and culture during the post-Weimar era, Handelman nevertheless silently ignores what genuinely discriminates negative mathematics as a constituent intellectual predecessor of the Frankfurt School critical theory. Instead, Handelman simply and contrarily refers to Horkheimer and Adorno's dismissal of mathematics that became influential among their circle, supposing the first generation's forgetfulness of these lost mathematical origins. This silence is intriguing because it is not a type of silence that reveals something inexpressible.

\section{Critical Theory of Negative Mathematics}

Interestingly, we may subscribe from Bolaños's essay "What is Critical Theory?" 45 the three fundamental normative claims which encapsulate the emancipatory program of the Frankfurt School critical theory in order to examine whether the Frankfurt School tradition accommodates a place for Scholem, Rosenzweig, and Kracauer in the intellectual origins of the Institut. According to Bolaños, what distinguishes the critical direction of theory envisioned by Horkheimer from traditional theory are the following:

\footnotetext{
${ }^{43}$ Ibid., 181.

${ }^{44}$ Ibid., 10.

45 Paolo Bolaños, "What is Critical Theory: Max Horkheimer and the Makings of the Frankfurt School Tradition," Mabini Review, 2 (2013), 6, 17; See also Max Horkheimer, "Traditional and Critical Theory," in Critical Theory: Selected Essays, trans. by Matthew J. O'Connell (New York: Continuum, 1989).
}

(c) 2021 Jessie Joshua Z. Lino and Esmeralda A. Manlulu https://www.kritike.org/journal/issue 29/lino\&manlulu december2021.pdf ISSN 1908-7330

(c) BY-NC-ND 
(1) the anthropological turn of philosophical inquiry, which empathically recognizes the significance of human activity and the rational (and nonrational) elements that generates the materialist orientation in the study of real situations and events; (2) next would be the practical direction of theory towards both the emancipation from slavery and the abolition of social injustice, which considers the political importance of the existing quasitranscendental values, suturing both theory and practice in the Frankfurt School tradition; (3) finally, a critique from the standpoint beyond class categories, as Bolaños explains, "the revolutionary impulse need not be limited to the bourgeoisie-proletariat structure and could be located in different social structures beyond the system of labor." 46 If the aforementioned constitutes for Horkheimer the visions of the Frankfurt School tradition, we could extrapolate from these normative claims strong theoretical similarities with the constellation of ideas from Scholem, Rosenzweig, and Kracauer, as examined in Handelman's book. In briefly doing so, we may be able to express Handelman's seeming silence.

Beginning with anthropological character of doing philosophy, Handelman discovers in Scholem and Rosenzweig a particular emphasis on identifying human understanding as the subject of inquiry by negative mathematics. Specifically, it pertains to the attempt to problematize the various ways our rationality encounters human knowledge and experiences of negation as initial points of departure, allowing us to reveal the contradictions of majoritarian discourses and dominant symbolic registers, ultimately confirming truths from the real experiences of marginalization, exclusion, and isolation in the grand historical narratives available. This is the same with Kracauer when it comes to the corrective aim of projektionslehre: the transformation of a dominant rationality through its own projection of what human rationality ought to be. From here, the anthropological elements in negative mathematics generate the practical direction of the writings of Scholem, Rosenzweig, and Kracauer towards addressing the problems of oppression and social injustice. Scholem's elaboration of the meaning of silence represent the mute speech of the exiled voices silenced by the dominant authorities in historical discourses. It is similar to Rosenzweig's metaphorical discussions on the differential, suggesting that all narratives (e.g., Judaism, Christianity, etc.) are essential on their own uniqueness within history in toto, like differentials being of equal importance within the structural continuum. And for his part, Kracauer's geometrical projection entails the transformation of the material dimension of our experience and culture, penetrating into the sensible coordinates to reconfigure spaces of marginalization and exclusion. But perhaps what parallels these thinkers of

${ }^{46}$ Bolaños, "What is Critical Theory?," 11.

(c) 2021 Jessie Joshua Z. Lino and Esmeralda A. Manlulu https://www.kritike.org/journal/issue 29/lino\&manlulu december2021.pdf

ISSN 1908-7330 


\section{FOR A THEORY}

negative mathematics with the Frankfurt School tradition is the third normative claim, which describes their research variable: For Scholem, Rosenzweig, and Kracauer, critique need not come from the formal categorization of class structures. The mathematical enterprise, given that it provides their philosophies and social theories the tools necessary to examine the constitutive aspects of negativity, is critique per se of the state of things and simultaneously a point of conjunction and intervention between thought and reality. Though it could be loosely argued that it is primarily their Jewish roots that which fueled Scholem, Rosenzweig, and Kracauer's intertwining of mathematics and philosophy. But Handelman was careful enough to recognize that critique can come from anywhere, and that the Judaism during the Weimar and post-Weimar Republic was a marginalized sector not only in economics but also in the academe, culture, politics, religion, and society in general. And it is in this over-marginalization of the Jews, being part of society without really having part of it (borrowing the idea from Jacques Rancière), that which allows them to transgress any social categorization, and thus enabling Scholem, Rosenzweig, and Kracauer to criticize the wrongdoings of oligarchic rule, oblivious histories, and oppressive systems from the standpoint and language of non-identity-a critique beyond identities, class categories, and territories as variables, i.e., a critique that comes from anywhere.

This ambit supplication to Handelman's work above seems to reflect the majorly exploratory nature of The Mathematical Imagination, specifically in its archeological rediscovery of the rich intellectual and mathematical heritage of Scholem, Rosenzweig, and Kracauer to the Institut für Sozialforschung. However, one should not neglect the intentions of the book and the implications of its discoveries. Handelman's work describes the prospects for critical theory and the importance of the role it plays in the digital technological age, hoping to show these prospects from the potentials of mathematical methodologies which thinkers prior to the Institut were able to utilize in their own struggle against social injustices. Negative mathematics contributes a theory of critique which are yet to be nominated as additions to the normative claims of the Frankfurt School tradition-to name a significantly few: (1) the possibility of knowledge in spite of skepticism and relativism through mathematical foundationalism; (2) new dimensions in the critique of disjunctions between life (experience) and thought (logic) through mathematical representations; (3) emancipatory model of mathematical expressibility; (4) and the immanence of mathematical truths in philosophical inquiry. These lessons are the strengths not only of Handelman's book, but

also of the Frankfurt School tradition when employed in the digital technological age.

(c) 2021 Jessie Joshua Z. Lino and Esmeralda A. Manlulu https://www.kritike.org/journal/issue 29/lino\&manlulu december2021.pdf ISSN 1908-7330

(cc) BY-NC-ND 


\section{Epilogue: Towards Digital Humanities}

In a world that moves towards its technologization and digitalization, mathematics ought to be relinquished from its apolitical vision by the positivists and refashion its critical potentials to deal with the various forms of negativity (e.g., absence, erasure, lack, division, disjunctions, privation, etc.) in the hopes of realizing the emancipatory program of critical social theory. Like the philosophical style of the early critical theorists, Handelman argues (in the Conclusion) that negative mathematics does not offer an alternative to despoiled systems of oppressive orders, but rather modes of analyzing and intervening in the contemporary world, which make use of the analytic advantages of mathematics and the actuarial sciences without losing sight of the political, social and cultural imperatives that constitutes what we know today as critical theory. ${ }^{47}$ Negative mathematics draws out the critical potential of the digital humanities, using its computational and digital approaches in addressing the problems of political quietism, colonial education, historical discontinuities, and modes of social exclusions caused by the combined negligence of neoliberal industrialization and globalization amidst a progressing world. Against the neoliberal interventions with knowledge-production, the mathematically-informed approaches such as cultural analytics, computational demographics, ethnological statistics, and distant reading not only use algorithms to examine patterns and codifications in order to analyze behaviors and canon of works which are almost impossible to read in a lifetime. More importantly, they also allow the digitalization of open-access text and sources in order to free and democratize knowledge to everyone. This is a specifically important solution to the problem of lack of access to knowledge for minoritarian individuals and groups, which is essential for their "technological and institutional power to create, maintain, and preserve" their minoritarian cultures, erased histories, forgotten legacies, and tolerated norms. ${ }^{48}$ Negative mathematics, through the digital humanities, expands the horizon of the epistemological limits for the marginalized communities against the forms of digital and technological domination of the contemporary world.

There is a potted literary aftertaste to Kracauer's lessons on projection and the role of the critic if readers are to read and re-read the rest and previous chapters, as there is no doubt about Handelman's intentions from the beginning, targeted on projecting the problem of mathematics as a mathematical concern and not as a non-philosophical concern that needs to be avoided. This is evident from the initial discussions, that is, if the Frankfurt

${ }^{47}$ Handelman, Mathematical Imagination, 189.

${ }^{48}$ Ibid., 194-195.

(c) 2021 Jessie Joshua Z. Lino and Esmeralda A. Manlulu https://www.kritike.org/journal/issue 29/lino\&manlulu december2021.pdf

ISSN 1908-7330 


\section{FOR A THEORY}

School critical theory equates the problems and contradictions of calculative reason and its enabling features to the rise of Fascism during their time, the point, however, is not to entirely dismiss (the way Horkheimer and Adorno did) but to establish a radical model of mathematics, generated from its own negativities, projected against its progenitors of political quietism (i.e., the mathematics envisioned by the logical positivists), and ultimately against those who use it as an apparatus for oppressing others.

Meanwhile, in another distant world that is French philosophy, the intertwining of philosophy (as critical theory) and mathematics was never entirely new. It was the contemporary French thinkers who clearly saw theoretical autonomy and valuable truths from mathematics beyond its historical approximation by continental rationalism of the $16^{\text {th }}$ to $18^{\text {th }}$ centuries and its stereotype role in today's analytic tradition of philosophy, advancing critical thought in a variety of ways: Gaston Bachelard's antiphenomenological reference to architectural science in elaborating the lyrical magnificence of experience, Jacques Lacan's constant use of mathemes in explaining the nature and mechanisms of the unconscious, Gilles Deleuze's notion of multiplicity being influenced by Riemann's hypothesis, Alain Badiou's necessary incorporation of Cantorian set theory into philosophy, Quentin Meillassoux's celebration of mathematical precision in spite of reality's hyper-chaos, among others. And even long before them, we are reminded too of the academic and historical prestige of the quadrivium: that arithmetic, astronomy, music, and geometry, as the liberal arts of numbers, were all essential disciplines not only for the formation of a universal idea of reality in toto, but more importantly for the formation of the human being in quest for reasoned truth towards the good life. It is fortunate that, with the merit of The Mathematical Imagination, we may now refer to Scholem, Rosenzweig, and Kracauer's contributions for a theory that is both critical and mathematical within the Frankfurt School tradition. Handelman presents to us a way out of our naiveté to this potential of mathematics in doing critical theory, more so in doing it here in the Philippines where some scholars on critical theory do not have that same level of enthusiasm for mathematics, thinking that it merely disregards critique and the critical studies of art, culture, literature, and other related fields. ${ }^{49}$ But we do wonder, at this point,

49 This, however, is not a sweeping generalization. It is noteworthy to mention a few Filipino practitioners of critical theory who still maintained spaces for engaging with either the topic of mathematics and the numerical disciplines per se, or the use of quantitative and statistical approaches to theory and computer-aided methods of textual analysis: Agustin Martin Rodriguez's Governing the Other: Exploring the Discourse of Democracy in a Multiverse of Reason provided a demographic analysis of grassroot governance in the exploration of the nature of democracy in the Philippines' multiverse of rationalities; Walden Bello's The Anti-Development State: The Political Economy of Permanent Crisis in the Philippines (co-written with Marissa de Guzman, Mary Lou Malig, and Herbert Docena) elaborated a comprehensive (and painful)

(c) 2021 Jessie Joshua Z. Lino and Esmeralda A. Manlulu https://www.kritike.org/journal/issue 29/lino\&manlulu december2021.pdf ISSN 1908-7330

(c) $)$ BY-NC-ND 
if our local scholars being less of enthusiasts reveal to us not a naiveté to the intellectual heritage of Scholem, Rosenzweig, and Kracauer, but rather a symptom of a growing obsession with their own disdain to anything related to the mathematics which simplistically describe as yet another apparatus within the tyranny of metrics. In the end, perhaps all of us could learn something in being faithful to the task Deleuze has for philosophy: "There is no need to fear or hope, but only to look for new weapons." 50

Department of Philosophy University of Santo Tomas, Philippines

College of Arts and Sciences \& Senior High School Department Manila Tytana Colleges, Philippines

\section{References}

Benjamin, Walter, Early Writing: 1910-1917 (Cambridge, Massachusetts: The Belknap Press of Harvard University Press, 2011).

Bolaños, Paolo, "Philosophy from the Standpoint of Damaged Life: Adorno on the Ethical Character of Thinking," in Budhi, 16 (2012).

"What is Critical Theory: Max Horkheimer and the Makings of the Frankfurt School Tradition," in Mabini Review, 2 (2013).

Briggs, W., Lyle Cochran, Bernard Gillett, and Eric Schulz, Calculus: Early Transcendentals, 3rd ed. (New Jersey: Pearson Education, Inc.: 2019).

Deleuze, Gilles, "Postscript on the Societies of Control," October, 59 (Winter 1992).

Feenberg, Andrew, The Philosophy of Praxis: Marx, Lukács and the Frankfurt School (London: Verso, 2014).

Geuss, Raymond, Outside Ethics (Princeton and Oxford: Princeton University Press, 2006).

examination of the poverty experienced by the Filipino people, and is suggestive of a development strategy anchored from quantitative economic data gathered from real experiences; Ramon Guillermo's Translation and Revolution: A Study of Jose Rizal's Guillermo Tell, a pioneering work on Philippine digital humanities, used computer-aided techniques of discursive and textual analysis to highlight the ideological dynamics of $19^{\text {th }}$ century nationalism in the Philippines; Filomeno Aguilar Jr.'s Peripheries: Histories of Anti-Marginality examines multiplicity of economic data supported by historical narratives from the margins (particularly the rice and sugar industries outside the center) that determine the structural dynamics of national historical change; Franz Giuseppe Cortez's essay "Critical Business Ethics: Contributions and Challenges" extends the lessons from Frankfurt School critical theory to engaging ethical questions encountered from the practical disciplines of business, finance, and the actuarial sciences; and Jayson Jimenez's essay "Kant and Precolonial Mathematics" aims to explore philosophically the intuitive precolonial ethnomathematics of the Angono Petroglyphs here in the Philippines.

${ }^{50}$ Gilles Deleuze, "Postscript on the Societies of Control," October, 59 (Winter 1992), 4.

(c) 2021 Jessie Joshua Z. Lino and Esmeralda A. Manlulu

https://www.kritike.org/journal/issue 29/lino\&manlulu december2021.pdf

ISSN 1908-7330

(cc) BY-NC-ND 


\section{FOR A THEORY}

Handelman, Matthew, The Mathematical Imagination: On the Origins and Promise of Critical Theory (New York: Fordham University Press, 2019).

Horkheimer, Max and Theodore W. Adorno, Dialectic of Enlightenment: Philosophical Fragments, trans. by Edmund Jephcott, ed. by Gunzelin Schmid Noerr (Stanford, California: Stanford University Press, 2002).

Horkheimer, Max, Eclipse of Reason (New York: Continuum Publishing Company, Inc., 2004).

"Traditional and Critical Theory," in Critical Theory: Selected Essays, trans. by Matthew J. O'Connell (New York: Continuum, 1989).

Husserl, Edmund, Crisis of the European Sciences and Transcendental Phenomenology: An Introduction to Phenomenological Philosophy, trans. by David Carr (Evanston: Northwestern University Press 1970).

Jay, Martin, Splinters in Your Eyes: Frankfurt School Provocations (London: Verso, 2020).

The Dialectical Imagination: A History of the Frankfurt School and Institute of Social Research, 1923-1950 (Berkeley, California: University of California Press, 1996)

Jeffries, Stuart, Grand Hotel Abyss: The Lives of the Frankfurt School (London: Verso, 2017).

Marcuse, Hebert, Negations, trans. by Jeremy J. Shapiro (London: MayFly Books, 2009).

"The Problem of Social Change in the Technological Society," in Collected Papers of Herbert Marcuse, Volume Two: Towards a Critical Theory of Society, ed. by Douglas Kellner (London: Routledge, 2001).

Muller, Jerry Z., The Tyranny of Metrics (New Jersey: Princeton University Press, 2018).

Rodriguez, Agustin Martin G., "Problematizing Critical Theory: Arriving at a More Critical Theory," in Kritike, 12 (April 2019).

(c) 2021 Jessie Joshua Z. Lino and Esmeralda A. Manlulu https://www.kritike.org/journal/issue 29/lino\&manlulu december2021.pdf ISSN 1908-7330 